Meta

Journal des traducteurs

Translators' Journal

\title{
Tell Me Not: Comments on P. Dasgupta
}

\section{Otto M. Ikome}

Volume 39, numéro 2, juin 1994

La traduction vue de l'extérieur - Translation: a view from the outside

URI : https://id.erudit.org/iderudit/003164ar

DOI : https://doi.org/10.7202/003164ar

Aller au sommaire du numéro

Éditeur(s)

Les Presses de l'Université de Montréal

ISSN

0026-0452 (imprimé)

1492-1421 (numérique)

Découvrir la revue

Citer cet article

Ikome, O. M. (1994). Tell Me Not: Comments on P. Dasgupta. Meta, 39(2),

397-400. https://doi.org/10.7202/003164ar

\section{Résumé de l'article}

Dasgupta semble venir au secours des traducteurs, en leur proposant une issue à leur dilemme : emprunter la pragmatique (linguistique) pour se créer un créneau digne de respect et de reconnaissance académique et scientifique. Non, merci, dirait un traducteur. Je l'ai déjà mon créneau : ne me dites pas comment réfléchir pour moi-même ! L'appel du « linguiste » au traducteur de se doter d'une compétence en linguistique et non pas d'une compétence linguistique, afin de maîtriser l'outil scientifique de formulation théorique, est un " coup bas » académique ou du moins un manque de compréhension ou d'appréciation de ce que sont la traduction et les théories qui sont à la base de sa pratique actuelle.
Tous droits réservés @ Les Presses de l'Université de Montréal, 1994
Ce document est protégé par la loi sur le droit d'auteur. L'utilisation des services d’Érudit (y compris la reproduction) est assujettie à sa politique d'utilisation que vous pouvez consulter en ligne.

https://apropos.erudit.org/fr/usagers/politique-dutilisation/ 


\title{
TELL ME NOT: COMMENTS ON P. DASGUPTA
}

OTTO M. IKOME

Télé-université, Montréal, Canada

\begin{abstract}
Résumé
Dasgupta semble venir au secours des traducteurs, en leur proposant une issue à leur dilemme: emprunter la pragmatique (linguistique) pour se créer un créneau digne de respect et de reconnaissance académique et scientifique. Non, merci, dirait un traducteur. Je l'ai déjà mon créneau: ne me dites pas comment réfléchir pour moi-même! L'appel du «linguiste» au traducteur de se doter d'une compétence en linguistique et non pas d'une compétence linguistique, afin de maîtriser l'outil scientifique de formulation théorique, est un "coup bas» académique ou du moins un manque de compréhension ou d'appréciation de ce que sont la traduction et les théories qui sont à la base de sa pratique actuelle.
\end{abstract}

To be fair and accurate, we will review Dasgupta's article "Translation and the Application of Linguistics" in this issue, in conjunction with an earlier article "Outgrowing Quine: Towards Substantivism in the Theory of Translation", published elsewhere. To examine the current article in isolation would not do justice to the author considering his demonstrated aptitude and competence in theoretical formulation and critical analysis (witness P. Dasgupta 1987, 1988, 1989). Although he sometimes loses us in the maze of his intricate analysis in the present article, the fact that this article is an addendum to the more powerful and clearly articulated "Outgrowing Quine..." article helps negotiate the maze.

Both articles raise an interesting issue that may have farreaching implications in the formulation of translation theory: that "future research exploring the ancient Indian philosophical and grammatical traditions" couched in an impressionist programme, could provide an alternative view to the traditional western thought especially set in expressionism. It is worthwhile noting that P. Dasgupta is not alone, and probably not the first to suggest that the Indian sub-continent has an array of traditions that would offer linguistics, language contact, cultural exchange and, most of all, translation research, with a rich mine for theoretical evaluation and formulation (see U. N. Singh 1989, and his allusions to Amitabha Gupta 1988 and Indrapath Chondhuri 1989).

P. Dasguspta decries the inadequacy, or rather the inaccuracy of the abstract Quinean vestiges of expressionism which, according to him, embody a "tradition guilty of a tendency to view languages as being systems of expression which are in principle mutually transparent ${ }^{1 "}$. To this abstract expressionist programme he put forward a concrete impressionist programme which in fact implements the substantivist conception of language. Of the two thoughts that emerge from his argument;

1) that the substantivist conception of language and translation is embedded in Idian linguistic thought and

2) that if taken for granted, translation were a mere extension and application of linguistics, then the formulation of any credible translation theory necessarily needs a 
linguistic theory (such as that embodied in Bhartrihari's Spark Theory), we need to check and balance the facts.

While P. Dasgupta gives the impression of having the ultimate solution in the formulation of a concrete translation theory, it is fair to say he is perhaps counting his chickens before they hatch as he fails to operationalize his solution. The alternative put forward by U. N. Singh (as we will see later) may not only resolve the impasse but would be more palatable to translators to whom this debate is addressed. Outgrowing Quine and putting forward a non-western approach to the formulation of a linguistic theory, and any other for that matter, is not only laudable but long overdue. But where does the translator, western, Indian or other, fit in this external debate as to what he should be thinking about, especially when P. Dasgupta says the translator cannot read or comprehend the volumes that linguistics offers: Maybe a pragmatic translator can, when he really needs to!

The fact is, that mechanical imagery in the name of science is not science itself; abstract philosophizing as a demonstration of scientific reflection, does not necessarily make theory out of a spark formulation embodied in linguistics. As we mentioned earlier, we want to laud P. Dasgupta for courageously facing up to some western claims, particulary the ones with respect to truth, enlightenment and technological prowess. In suggesting an Indian model, using Bhartrihari's philosophy of language akin to modern generative grammar, $P$. Dasgupta is forging his way forward towards a theoretical breakthrough in the theory of translation. Sadly though, his application of the theoretical framework of linguistics and/or pragmatics to the abstraction of translation is not only antagonistic but perhaps even arrogant, especially when his Indian style is applied backward.

We see in his critique of the translation enterprise, an engagement in an enterprise of equal proportion couched in the scientific expertise of linguistics, as opposed to the humanistic indulgence of translation. We will define and try to strike a delicate balance here between Quine's $(1953,1960)$ stand that translation is impossible based on his expressionist approach, and Dasgupta's (1989) self-conscious impressionist approach to the task of translating. To do this, we will weigh his substantivist approach against the translator's actual practice. While expressionism is the function of the source text in expressing fundamental meaning - on which all subsequent meaning depends, impressionism is a more credible version of the concrete view of translation which finds roots in classical Indian linguistic thought by implementing the substantivist conception of language and translation. Substantivism is the realistic approach to the substance of language, as well as the substance of cultural horizons within which linguistic objectives arise, with a presumption that language is situated in discourse. Even though objective impresionism gives the translator credit for being the manager of the proximation process that closes even radical cross-linguistic gaps, it appears that $\mathrm{P}$. Dasgupta fails to consider actual translation practice as the basis and object of formulating a theory that truly reflects the enterprise of bridging more than just thought. It includes the cultures on which they are based.

Narayana Singh (1989: quoted by U. N. Singh) calls the accessment of translation practice an inductive theory of translation, which is likely to go against the theoretical position of generative grammarians such as Chomsky (1972). If translation is the work of explicating equivalences and complementarities, and therefore involves an important procedure in the general enterprise of proximation (P. Dasgupta 1989), then "the future of a translation theory", as U. N. Singh puts it, "crucially depends on the practice of a translator". Such an inductive theory will be based on a scientific study or analysis of the translator's difficulties, techniques, options, goals, style, methods, etc., of which linguistic 
analysis proper (especially of the expressionist mode), is only a part. This view is in line with Alokeranjan Dasgupta's (1988: alluded to in U. N. Singh) view that the practice of translating does indeed create theory.

P. Dasgupta suggests that theoretical abstraction should not be confused with actual practice, as "such rootedness in practice and loyalty to regional realities may lead to distrust of or impatience with the scientific enterprise of (say) linguistics" (P. Dasgupta 1991). We will rather agree with U. N. Singh that the linguistic theory of translation is not holistic either, given that a translation theory cannot merely aim at description and validation of lexical and grammatical manipulations meant to attain a semantic equivalent. In fact, although P. Dasgupta has convincingly demonstrated that a growth away from Quine is not only necessary for the freedom and independence of the translator, but is also critical in defining the role and enterprise of translating, he nevertheless ironically goes on (in his current article) to restrict that freedom by telling the translator what to do.

On freedom: if pragmatics can help translators in their enterprise, they will not only gladly use it as they would mathematics or computer science, but they need not be summoned by linguists to do so as if it were a favor or a must. In fact, a translator's independence is not a function of his dependence on tools of research or public knowledge. As "actors in an inter-cognitive situation", translators are not only better placed to seek information from resource persons but also know how to share it as a way of generating an ongoing support system for future consultation.

On independence: we reiterated before that the way to independence is not through a truncated dependence; originality and self-determination are the pragmatic way to go it is not a question of whether or not "translators choose to take [any given] assistance", it is a question of building a theoretical base that responds to the abstraction of concise applications of translation practice, i.e. the bridge between the substantive and the formal in translation.

We have so far refrained from commenting on P. Dasgupta's apparently successful use of the disconcerting puurva-paksha versus siddhaanta-paksha rhetorical opposition of classical Indian style. Is it possible that his achievement here has been to lose us in the meta-abstract away from an apparent Quinean chaos, into a less than obvious Bhartrihari order of genuine freedom? Whereas "Outgrowing Quine: Towards Substantivism in the Theory of Translation" scores an eloquent goal in the review and re-shaping of translation theory based on linguistics, "Translation and the Application of Linguistics" is, I'm afraid, a rather lame follow up on the application of linguistics to the development of such a theory. In fact, the issue of linguistics and translation - so appropriately developed in the first article - doesn't seem to be central at all in this later piece.

To develop a new and independent approach to account for the practice of translation, one may have to shift from the Western stranglehold of theory and knowledge and look elsewhere, say the Indian-subcontinent. If pragmatics were to make the task easier it will be used on an inter-disciplinary basis, but in all, we believe translators should have the last word, even as they listen to advice and endure criticism. The task of translators (Benjamin 1969) is more than just producing equivalences; it includes reflection on the principles surrounding this task. They are the source of crucial data and practical experience on which any theoretical formulation ought to be based.

Notes

1. This Western tradition derives from a devine logos which has been amply elucidated in Biblical transcripts of the Word of God - a Word inspired by God, hence the devine inspiration of language from the Christian and Western points of view. 


\section{REFERENCES}

BENJAMIN, Walter (1960): "The Task of the Translator", Illuminations, (Tr. by Harry Zohn), New York, Schooken.

CHOMSKY, Noam (1972): "Deep Structure, Surface Structure, and Semantic Interpretation", Studies on Semantics in Generative Grammar, The Hague, Mouton.

DASGUPTA, Probal (1987): "The Intimate Friend", Journal of Indian Philosophy, 15, pp. 187-205.

DASGUPTA, Probal (1988): "The External Reality of Linguistic Descriptions", Canadian Journal of Linguistics 33:4.

DASGUPTA, Probal (1989): "Outgrowing Quine: Towards Substantivism in the Theory of Translation", International Journal of Translation, 1:2, pp. 13-41.

QUINE, Willard V. O. (1953): From a Logical Point of View, (2nd Ed. 1961), Cambridge, MA, Harvard University Press.

QUINE, Willard V. O. (1960): Word and Object, Cambridge, MA, MIT Press.

SINGH, Undayanarayana N. (1989): "Translation Theory: an Attempt at Understanding", International Journal of Translation, 1:2, pp. 69-78. 